\title{
Penapisan Isolat Rizobakteri Indigenos untuk Pengendalian Ganoderma boninense pada Bibit Kelapa Sawit (Elaeis guineensis Jacq.)
}

\section{(Screening of Indigenous Rhizobacteria Isolate for Control of Ganoderma boninense on Oil Palm Seedlings [Elaeis guineensis Jacq.])}

Yulmira Yanti ${ }^{1{ }^{*}}$, Arnetti $^{1)}$, Imam Rifai ${ }^{2)}$

1) Program Studi Proteksi Tanaman Fakultas Pertanian Universitas Andalas, Jl. Unand Kampus Limau Manis Kec. Pauh Kota Padang, Telp./Fax.: (0751)72701/(0751)72702, Kode Pos: 25163 dan

2) Pascasarjana Fakultas Pertanian Universitas Andalas Padang, Jl. Unand Kampus Limau Manis Kec. Pauh Kota Padang, Telp./Fax.: (0751)72701/(0751)72702, Kode Pos: 25163

E-mail:yy.anthie79@gmail.com; mira23@agr.unand.ac.id

\begin{abstract}
Basal stem rot (Ganoderma boninense) is one of the main diseases of oil palm. The objective of the research was to obtain indigenous rhizobacteria (RBI) isolate which have the ability increase growth and to control basal stem rot on oil palm seedlings in planta. Experimental research consists of 3 stages by using Completely Randomized Design (CRD). Indigenous rhizobacteria isolate testing as plant growth promoting rhizobacteria (PGPR) and to control of $\underline{G}$. boninense on pre-nursery of oil palm consisted of 29 treatments (27 RBI isolates, without $\underline{G}$. boninense inoculation as positive control, and $\underline{G}$. boninense inoculation as negative control) with 5 replications each. Data were analyzed by variance, if the result significantly different, it was continued by using Least Significance Different (LSD) at 5\% level. The results showed that two of the best isolates were RZ2E 2.1 and RZ2E 1.2 which were able to increase growth and were able to suppress the development of basal stem rot G. boninense.
\end{abstract}

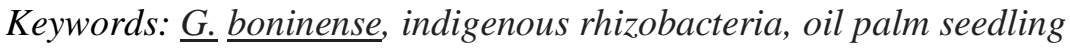

DOI: http://dx.doi.org/10.25181/jaip.v7i2.1156

Diterima: 6 Mei 2019 / Disetujui: 12 September 2019 / Diterbitkan: 5 Oktober 2019

\section{PENDAHULUAN}

Penyakit busuk pangkal batang (BPB) yang disebabkan oleh Ganoderma boninense merupakan penyakit utama pada tanaman kelapa sawit dan merupakan penyakit penting pada perkebunan kelapa sawit di Asia Tenggara (Chong et al., 2011). Penyakit ini dilaporkan menyebabkan kerugian sekitar 50-80\% per ha. Indonesia dan Malaysia merupakan negara dengan kerugian terbesar akibat BPB. Kerugian akibat penyakit BPB diperkirakan mencapai 500 juta USD/tahun (Rees et al., 2012). Penyakit BPB sulit dikendalikan, sebab G. boninense merupakan patogen tular tanah yang memiliki kisaran inang luas serta memiliki struktur khusus yang berdampak 
pada kemampuan bertahan dan menginfeksi tanaman target seperti spora istirahat berupa klamidospora dan struktur pseudosklerotia (Susanto et al., 2014).

Upaya pengendalian yang telah dilakukan terhadap jamur $G$. boninense, yaitu pengendalian secara fisik melalui teknik sanitasi dan menggunakan fungsida sintetis. Penggunaan fungsida sintetis dalam jangka panjang akan memberikan dampak negatif bagi lingkungan seperti terbunuhnya organisme non-patogen, meracuni manusia, hewan, serta terjadinya resistensi terhadap patogen (Susanto et al., 2005). Alternatif pengendalian yang aman bagi lingkungan untuk menekan serangan G.boninense adalah menggunakan agens biokontrol dari kelompok mikroorganisme (Bivi et al., 2010). Mikroorganisme yang sudah banyak dilaporkan mampu sebagai agens biokontrol adalah rizobakteri dari kelompok plant growth promoting rhizobacteria (PGPR) (Fernando et al., 2005).

Rizobakteri merupakan kelompok bakteri yang dapat meningkatkan kualitas pertumbuhan tanaman baik secara langsung maupun tidak langsung. Rizobakteri juga memberi efek antagonis terhadap patogen tanaman melalui beberapa cara, yaitu produksi siderofor, enzim kitinase, parasitisme, kompetisi sumber nutrisi, serta menginduksi ketahanan tanaman secara sistemik (Beneduzi et al., 2012). Pengendalian penyakit tanaman menggunakan rizobakteri merupakan salah satu alternatif pengendalian yang dapat digunakan, ramah lingkungan, berkesinambungan, dapat diperbanyak dengan teknologi yang sederhana dan mudah diaplikasikan, serta dapat diintegrasikan dalam program pengendalian hama terpadu (Yanti et al., 2013). Keberadaan rizobakteri di rizosfir dilaporkan mampu membuat seluruh bagian tanaman termasuk bagian pucuk menjadi lebih tahan terhadap patogen (Figueiredo et al.,, 2010). Rizobakteri juga telah dilaporkan mampu menginduksi ketahanan tanaman terhadap penyakit yang disebabkan oleh bakteri, jamur, dan virus (Halfeld-vieira et al., 2006).

\section{METODE PENELITIAN}

Penelitian dilaksanakan pada Januari sampai dengan Juli 2018. Pengambilan sampel tanah dilakukan di PTPN IV kebun Bahjambi Kabupaten Simalungun Sumatera Utara, isolasi dan karakterisasi antagonis rizobakteri dilakukan di Laboratorium Mikrobiologi, dan uji in planta dilakukan di rumah setengah bayang Fakultas Pertanian Universitas Andalas Padang. Bahan-bahan yang digunakan dalam penelitian adalah tanah tanaman kelapa sawit yang sehat, inokulum Ganoderma boninense koleksi PPKS Marihat Pematang Siantar, benih kelapa sawit varietas Tenera yang berasal dari PPKS Medan, Alkohol 70\%, KOH 3\%, Aquades, media Nutrient Agar (NA), media Nutrient Both (NB), media King's B, media Kitin agar, polybag volume $2 \mathrm{~kg}$ dengan ukuran $22 \mathrm{~cm}$ $\mathrm{x} 14 \mathrm{~cm}$, tanaman bunga pukul empat (Mirabilis jalapa), kertas saring, tissue, alluminium foil, tanah steril, air kelapa, dan kertas label. Alat-alat yang digunakan dalam penelitian adalah cawan petri, gelas piala, gelas ukur, pinset,botol schott, pipet tetes, mikro pipet, spatula, bor tanah, erlenmeyer, stir bar, microtube, hotplate stirrer, rotary shaker horizontal, alat injeksi $1 \mathrm{ml}$, autoclave, laminar 
air flow, cangkul, batang pengaduk, tabung reaksi, timbangan analitik, vortex, kompor listrik gelas objek, gelas penutup, bunsen, korek api, mortar, jarum ose, pisau, alat dokumentasi, dan alat tulis.

Penelitian menggunakan Rancangan Acak Lengkap (RAL) dengan 29 perlakuan dan 5 ulangan. Seleksi dilakukan secara in planta perlakuan yang digunakan adalah introduksi isolat rizobakteri indigenos 27 isolat, 1 kontrol positif (+) (tanpa inokulasi G. boninense dan tanpa introduksi isolat rizobakteri indigenos), dan 1 kontrol negatif (-) (inokulasi G. boninese tanpa introduksi isolat rizobakteri indigenos) penempatan percobaan dilakukan secara acak. Variabel yang diamati yaitu karakter morfologis dan fisiologis rizobakteri indigenos (bentuk koloni, elevasi, bentuk permukaan koloni, ukuran dan warna koloni), pertumbuhan tanaman (tinggi, jumlah daun, berat basah, dan berat kering), keterjadian penyakit (\%) dan keparahan penyakit (\%). Data dianalisis dengan sidik ragam, apabila berbeda nyata dilanjutkan dengan uji Least Significance Difference (LSD) pada taraf nyata 5\%. Kejadian penyakit $G$. boninense tanaman kelapa sawit dapat diketahui dengan cara mengamati gejala eksternal pada tanaman (Suryanto et al., 2012) dengan rumus:

$$
\mathrm{I}=\frac{n}{N} \times 100 \%
$$

Keterangan:

$\mathrm{I}=$ Kejadian penyakit

$\mathrm{n}=$ Jumlah unit tanaman terinfeksi

$\mathrm{N}=$ Total jumlah unit tanaman yang diamati

Pengamatan keparahan penyakit dilakukan pada akhir penelitian setelah 16 MST dengan menghitung intensitas penyakit berdasarkan rumus yaitu sebagai berikut:

$$
\mathrm{Kp}=\frac{\sum\left(n_{i} \times v_{i}\right)}{N \times Z} \times 100 \%
$$

Keterangan:

$\mathrm{Kp}=$ Keparahan penyakit

$\mathrm{n}_{\mathrm{i}}=$ Jumlah tanaman dengan skor ke- $\mathrm{i}$

$\mathrm{v}_{\mathrm{i}}=$ Nilai skala penyakit dari $\mathrm{i}=0,1,2$, sampai skor tertinggi

$\mathrm{N}=$ Jumlah tanaman yang diamati

$\mathrm{Z}=$ Skor tertinggi

Tabel 1. Skor tingkat serangan jamur Ganoderma boninense pada bibit kelapa sawit

\begin{tabular}{cl}
\hline Skor & \multicolumn{1}{c}{ Keterangan } \\
\hline 0 & Daun sehat atau normal \\
1 & Daun klorosis menguning \\
2 & Daun klorosis diikuti nekrosis (1-3 helai) \\
3 & Seluruh daun nekrosis (4 helai) \\
4 & Tanaman mati \\
\hline
\end{tabular}

Sumber: Abdullah et al., 2003 (modifikasi) 


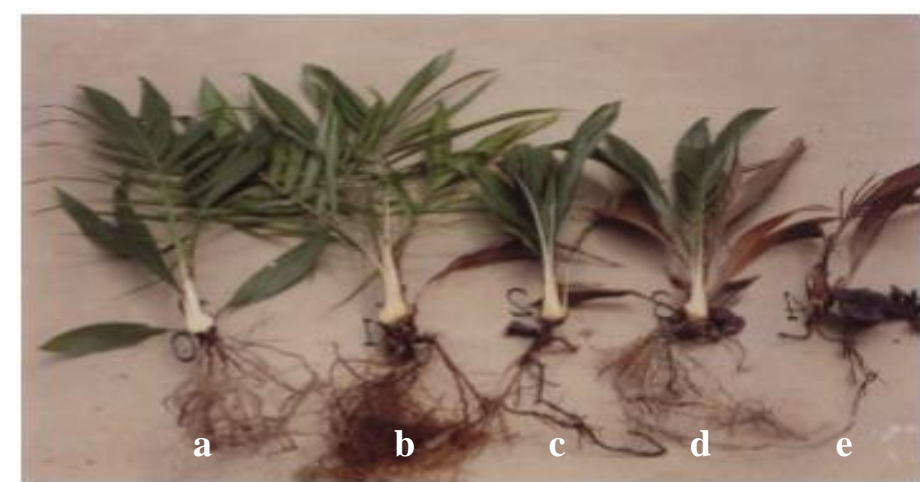

Gambar 1. Skor gejala penyakit busuk pangkal batang bibit kelapa sawit: a. Skala (0) daun sehat; b. Skala (1) daun klorosis (menguning); c. Skala (2) daun klorosis diikuti nekrosis;

d. Skala (3) seluruh daun nekrosis; dan e. Skala (4) tanaman mati

\section{HASIL DAN PEMBAHASAN}

\section{Karakter Isolat Rizobakteri Indigenos}

Isolat rizobakteri indigenos (RBI) yang diisolasi dari tanah perakaran kelapa sawit PTPN IV Kabupaten Simalungun diperoleh 27 isolat rizobakteri indigenos yang telah melalui uji hipersensitif (HR) dapat dilihat pada (Tabel 2). Karakter morfologis dan fisiologis rizobakteri indigenos yang diperoleh dapat dilihat pada (Gambar 2). Karakter fisiologis rizobakteri indigenos menunjukkan Gram positif (21 isolat), sedangkan Gram negatif (6 isolat), dua isolat RZ2E 2.1 dan RZ1E 2.1 mampu menghasilkan kitinase.
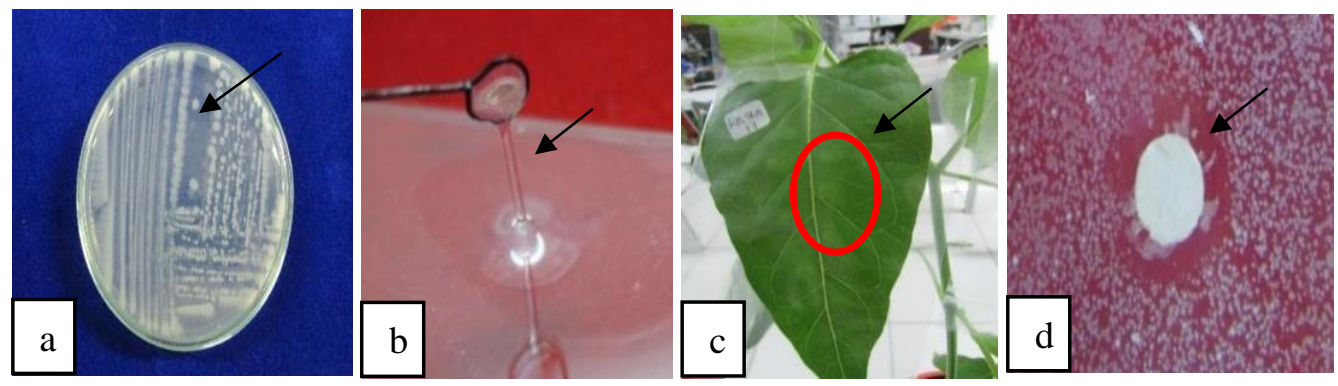

Gambar 2. Karakter morfologi: a. Isolat RZ1A 2.1; b. Reaksi gram negatif isolat RZ2B 1.1; c. Reaksi hipersensitif negatif isolat RZ2E 2.1; dan d. Aktivitas kitinase isolat RZ1E 2.1 pada media agar kitin $2 \times 24$ jam 
Tabel 2. Karakter morfologis dan fisiologis isolat rizobakteri indigenos dari tanah perakaran kelapa sawit PTPN IV

\begin{tabular}{|c|c|c|c|c|c|c|c|c|}
\hline Isolat & Bentuk & Elevasi & Tepi & $\begin{array}{c}\text { Ukuran } \\
\text { (cm) }\end{array}$ & Warna & HR & Gram & Kitinase \\
\hline RZ1A 1.1 & $\begin{array}{l}\text { Tidak } \\
\text { beraturan }\end{array}$ & Rata & Rata & 1,2 & Putih & - & + & - \\
\hline RZ1A 1.2 & Bulat & Cembung & Cembung & 1,1 & Putih & - & + & - \\
\hline RZ1A 1.3 & Bulat & Cembung & Cembung & 0,6 & Putih & - & + & - \\
\hline RZ1A 2.1 & $\begin{array}{l}\text { Tidak } \\
\text { beraturan }\end{array}$ & Rata & & 0,7 & Putih & - & + & - \\
\hline RZ1A 2.2 & Bulat & Rata & Berlapis & 1,4 & Putih & - & + & - \\
\hline RZ2A 1.1 & $\begin{array}{l}\text { Tidak } \\
\text { beraturan }\end{array}$ & Cembung & Rata & 1,8 & Putih & - & + & - \\
\hline RZ2A 2.2 & $\begin{array}{l}\text { Tidak } \\
\text { beraturan }\end{array}$ & Undulate & Berlapis & 1,5 & Putih & - & + & - \\
\hline RZ1B 1.1 & Bulat & Cembung & Rata & 1,3 & Putih & - & + & - \\
\hline RZ1B 2.1 & Bulat & Cembung & Berlapis & 0,5 & Putih & - & + & - \\
\hline RZ2B 1.1 & Bulat & Cembung & Rata & 0,2 & Krem & - & - & - \\
\hline RZ2B 2.1 & Bulat & Rata & Rata & 0,8 & Putih & - & + & - \\
\hline RZ1C 1.1 & $\begin{array}{l}\text { tidak } \\
\text { beraturan }\end{array}$ & Cembung & Berlapis & 1,4 & Putih & - & + & - \\
\hline RZ1C 2.1 & Bulat & Cembung & Rata & 1,2 & Putih & - & + & - \\
\hline RZ1C 2.2 & Bulat & Cembung & Berlapis & 1,1 & Putih & - & + & - \\
\hline RZ2C 1.1 & $\begin{array}{l}\text { Tidak } \\
\text { beraturan }\end{array}$ & Cembung & Rata & 1,3 & Putih & - & + & - \\
\hline RZ2C 2.1 & $\begin{array}{l}\text { tidak } \\
\text { beraturan }\end{array}$ & Cembung & Berlapis & 1,8 & Putih & - & + & - \\
\hline RZ2C 2.2 & Rhizoid & Rata & Berlapis & 0,9 & Putih & - & + & - \\
\hline RZ1D 1.1 & Bulat & Rata & Rata & 0,1 & Merah & - & - & - \\
\hline RZ1D 1.2 & Bulat & Cembung & Berlapis & 0,1 & Merah & - & + & - \\
\hline RZ1E 1.1 & Bulat & Cembung & Rata & 0,7 & Putih & - & + & - \\
\hline RZ1E 1.2 & Bulat & Cembung & Berlapis & 0,1 & Kuning & - & - & - \\
\hline RZ1E 2.1 & Bulat & Cembung & Rata & 1,1 & Putih & - & + & + \\
\hline RZ1E 2.2 & $\begin{array}{l}\text { Tidak } \\
\text { beraturan }\end{array}$ & Rata & Berlapis & 1,0 & Putih & - & + & - \\
\hline RZ2E 1.1 & Bulat & Cembung & Berlapis & 0,1 & Merah & - & - & - \\
\hline RZ2E 1.2 & Bulat & Rata & Rata & 0,1 & Merah & - & - & - \\
\hline RZ2E 1.3 & Bulat & Cembung & Rata & 1,4 & Merah & - & - & - \\
\hline RZ2E 2.1 & $\begin{array}{l}\text { Tidak } \\
\text { beraturan }\end{array}$ & Rata & Berlapis & 0,8 & Putih & - & + & + \\
\hline
\end{tabular}

\section{Pertumbuhan Tanaman}

Introduksi beberapa jenis rizobakteri indigenos menunjukkan pengaruh yang berbeda nyata terhadap tinggi, jumlah daun, berat basah, dan berat kering (Tabel 3). Peranan rizobakteri indigenos sebagai PGPR pada bibit kelapa sawit dapat dilihat pada isolat RZ2E 1.2 dan RZ2E 2.1 yang merupakan isolat terbaik dalam meningkatkan pertumbuhan bibit kelapa sawit. Isolat RZ2E 1.2 memperlihatkan efektivitas tinggi tanaman $21,05 \%$, dan efektivitas jumlah daun 50,21\%. Sementara isolat RZ2E 2.1 memperlihatkan efektivitas berat basah 65,51\% dan berat kering 72,94\%. 
Tabel 3. Rerata tinggi, jumlah daun, berat basah, dan berat kering, bibit kelapa sawit yang diintroduksi isolat rizobakteri indigenos 16 (MST)

\begin{tabular}{|c|c|c|c|c|c|c|c|c|c|c|c|}
\hline \multirow{2}{*}{$\begin{array}{l}\text { Perlakuan } \\
\text { RZ2E } 1.2\end{array}$} & \multicolumn{2}{|c|}{$\begin{array}{l}\text { Tinggi } \\
\text { (cm) }\end{array}$} & \multirow{2}{*}{\begin{tabular}{|c|}
$\begin{array}{c}\text { Eff } \\
(\%)\end{array}$ \\
21,05
\end{tabular}} & \multicolumn{2}{|c|}{$\begin{array}{c}\text { Jumlah } \\
\text { daun (helai) }\end{array}$} & \multirow{2}{*}{$\begin{array}{c}\begin{array}{c}\text { Eff } \\
(\%)\end{array} \\
50,21\end{array}$} & \multicolumn{2}{|c|}{$\begin{array}{l}\text { Berat basah } \\
\text { (g) }\end{array}$} & \multirow{2}{*}{\begin{tabular}{|c|}
$\begin{array}{c}\text { Eff } \\
(\%)\end{array}$ \\
18,62
\end{tabular}} & \multirow{2}{*}{$\begin{array}{c}\begin{array}{c}\text { Berat } \\
\text { Kering }(\mathbf{g})\end{array} \\
7,51\end{array}$} & \multirow{2}{*}{$\begin{array}{c}\begin{array}{c}\text { Eff } \\
(\%)\end{array} \\
72,24\end{array}$} \\
\hline & 30,66 & $\mathrm{a}$ & & 7,00 & $\mathrm{a}$ & & 17,20 & gh & & & \\
\hline RZ2E 2.1 & 28,33 & $\mathrm{~cd}$ & 11,84 & 6,00 & $\mathrm{bc}$ & 28,75 & 24,00 & $\mathrm{a}$ & 65,51 & 7,34 & 68,34 \\
\hline RZ1A 2.2 & 26,00 & ef & 2,64 & 5,00 & ef & 7,29 & 13,05 & $\mathrm{ij}$ & $-10,00$ & 7,33 & 68,11 \\
\hline RZ1B 1.1 & 25,33 & ef & 0 & 4,33 & fg & $-7,62$ & 17,85 & fg & 23,10 & 6,50 & 49,08 \\
\hline RZ1B 2.1 & 22,00 & fg & $-13,14$ & 4,33 & efg & $-7,62$ & 17,10 & $\mathrm{gh}$ & 17,93 & 5,92 & 35,77 \\
\hline RZ1E 1.1 & 27,66 & de & 9,20 & 5,33 & de & 14,37 & 15,55 & $\mathrm{ij}$ & 7,24 & 5,71 & 30,96 \\
\hline RZ1E 1.2 & 30,00 & $a b$ & 18,43 & 5,66 & $\mathrm{~cd}$ & 21,54 & 12,65 & ij & $-12,75$ & 5,51 & 26,37 \\
\hline RZ2A 1.1 & 23,66 & fg & $-6,59$ & 5,00 & ef & 7,29 & 13,00 & hij & $-10,34$ & 5,47 & 25,45 \\
\hline RZ2A 2.2 & 24,66 & fg & $-2,64$ & 4,66 & fg & 0 & 16,55 & $\mathrm{ij}$ & 14,13 & 5,42 & 24,31 \\
\hline RZ2B 1.1 & 29,33 & $\mathrm{bc}$ & 15,80 & 5,66 & $\mathrm{~cd}$ & 21,54 & 13,50 & hij & $-6,89$ & 5,14 & 17,88 \\
\hline RZ2C 1.1 & 27,33 & de & 7,90 & 5,66 & $\mathrm{~cd}$ & 21,54 & 21,15 & $\mathrm{c}$ & 45,86 & 5,08 & 16,51 \\
\hline RZ1A 1.2 & 21,33 & $\mathrm{~g}$ & $-15,79$ & 5,00 & ef & 7,29 & 11,40 & $\mathrm{ij}$ & $-21,37$ & 5,05 & 15,82 \\
\hline RZ1A 2.1 & 22,66 & fg & $-10,54$ & 5,66 & $\mathrm{~cd}$ & 21,54 & 17,50 & gh & 20,68 & 4,97 & 13,99 \\
\hline Kontrol + & 25,33 & ef & 0 & 4,66 & $\mathrm{fg}$ & 0 & 0 & $\mathrm{ij}$ & 0 & 4,86 & 11,46 \\
\hline RZ1C 1.1 & 27,33 & de & 7,90 & 5,33 & de & 14,37 & 15,30 & $\mathrm{ij}$ & 5,51 & 4,74 & 8,71 \\
\hline RZ1D 1.1 & 25,00 & fg & $-1,30$ & 4,66 & $\mathrm{fg}$ & 0 & 21,15 & $\mathrm{bc}$ & 45,86 & 4,45 & 9,00 \\
\hline RZ1A 1.1 & 24,66 & fg & $-2,64$ & 6,00 & $\mathrm{bc}$ & 28,75 & 10,50 & $\mathrm{ij}$ & $-27,58$ & 4,45 & 9,00 \\
\hline RZ1D 1.2 & 26,33 & ef & 3,95 & 4,33 & $\mathrm{fg}$ & $-7,62$ & 19,10 & $\mathrm{de}$ & 31,72 & 4,38 & 2,00 \\
\hline RZ1E 2.1 & 24,33 & fg & $-3,94$ & 5,66 & $\mathrm{~cd}$ & 21,54 & 20,30 & $\mathrm{~cd}$ & 40,00 & 4,36 & 0,00 \\
\hline RZ2C 2.1 & 27,66 & de & 9,20 & 6,66 & $\mathrm{~b}$ & 42,91 & 22,40 & $a b$ & 54,48 & 4,27 & $-2,06$ \\
\hline RZ2C 2.2 & 25,00 & fg & $-1,30$ & 5,66 & $\mathrm{~cd}$ & 21,54 & 19,10 & de & 31,72 & 3,85 & $-11,69$ \\
\hline RZ2E 1.1 & 24,50 & fg & $-3,27$ & 5,00 & ef & 7,29 & 8,10 & ef & 24,82 & 3,83 & $-12,15$ \\
\hline RZ2B 2.1 & 26,33 & ef & 3,95 & 5,66 & $\mathrm{~cd}$ & 21,54 & 20,55 & $\mathrm{~cd}$ & 41,72 & 3,78 & $-13,30$ \\
\hline RZ1A 1.3 & 22,66 & fg & $-10,54$ & 4,66 & fg & 0 & 9,70 & $\mathrm{ij}$ & $-33,10$ & 3,73 & $-14,44$ \\
\hline RZ1C 2.1 & 23,16 & fg & $-8,56$ & 3,66 & $\mathrm{~g}$ & $-21,45$ & 10,75 & hij & $-25,86$ & 3,73 & 14,44 \\
\hline RZ1C 2.2 & 26,00 & ef & 2,64 & 4,33 & fg & $-7,62$ & 17,10 & gh & 17,93 & 3,58 & $-17,88$ \\
\hline RZ1E 2.2 & 25,00 & fg & $-1,30$ & 5,00 & ef & 7,29 & 12,00 & $\mathrm{ij}$ & $-17,24$ & 3,04 & $-30,27$ \\
\hline RZ2E 1.3 & 21,33 & $\mathrm{~g}$ & $-15,79$ & 5,66 & $\mathrm{~cd}$ & 21,54 & 15,00 & $\mathrm{ij}$ & 3,44 & 2,52 & $-42,20$ \\
\hline
\end{tabular}

Keterangan: Angka-angka yang diikuti oleh huruf kecil yang sama pada lajur yang sama berbeda tidak nyata menurut LSD pada taraf 5\%

Adanya pengaruh peningkatan pertumbuhan bibit kelapa sawit dengan perlakuan rizobakteri indigenos diduga isolat tersebut berperan sebagai biostimultan dengan menghasilkan fitohormon bagi pertumbuhan tanaman. Beneduzi et al. (2012) menyatakan mekanisme PGPR dalam meningkatkan pertumbuhan tanaman melalui perananya sebagai biostimulan PGPR mampu menghasilkan atau mengubah konsentrasi hormon tanaman seperti asam indol asetat, asam giberelin, sitokinin, atau prekursornya (1-aminosiklopropena-1-karboksilat deaminase) di dalam tanaman yang dapat meningkatkan pertumbuhan tanaman. Sejalan dengan hasil penelitian Yanti et al., (2013) yang menyatakan bahwa aplikasi rizobakteri indigenos isolat P11Rz1.1. dan P14Rz1.1 mampu menghasilkan hormon tumbuh IAA sehingga dapat meningkatkan pertumbuhan tinggi tanaman, jumlah daun dan hasil tanaman kedelai. Hormon IAA mampu mempengaruhi proses fisiologi tanaman seperti pembelahan sel, pemanjangan sel, pertumbuhan akar, dominansi apikal, pembungaan dan gerak tropisme (Zhang et al., 2016).

Kejadian dan Keparahan Penyakit G. boninense pada Bibit Kelapa Sawit

Bibit kelapa sawit yang diintroduksi beberapa isolat rizobakteri indigenos menunjukkan 
pengaruh yang berbeda nyata terhadap kejadian dan keparahan penyakit $G$. boninense pada 90 hari setelah inokulasi (HSI). Terdapat tujuh isolat RZ2E 2.1, RZ1A 2.1, RZ1E 1.2, RZ2B 1.1 RZ2C 2.1, RZ1E 2.1 dan RZ2E 1.2 mampu menekan kejadian dan keparahan peyakit busuk pangkal batang sampai akhir pengamatan tidak menimbulkan gejala dengan efektivitas $100 \%$ dibanding kontrol dapat dilihat pada Tabel 4.

Tabel 4. Kejadian dan keparahan penyakit G. boninense pada bibit kelapa sawit 90 HSI

\begin{tabular}{|c|c|c|c|c|c|c|}
\hline \multirow{2}{*}{$\begin{array}{l}\text { Perlakuan } \\
\text { Kontrol }\end{array}$} & \multicolumn{2}{|c|}{ Kejadian Penyakit (\%) } & \multirow{2}{*}{$\begin{array}{c}\text { Eff } \% \\
0\end{array}$} & \multicolumn{2}{|c|}{ Keparahan Penyakit (\%) } & \multirow{2}{*}{$\begin{array}{c}\text { Eff \% } \\
0,00\end{array}$} \\
\hline & 100,0 & $\mathrm{a}$ & & 77,3 & $\mathrm{a}$ & \\
\hline RZ1B 1.1 & 100,0 & $\mathrm{a}$ & 0 & 16,0 & $\mathrm{e}$ & 79,30 \\
\hline RZ1E 2.2 & 100,0 & $\mathrm{a}$ & 0 & 66,7 & $\mathrm{~b}$ & 13,71 \\
\hline RZ2A 1.1 & 100,0 & $\mathrm{a}$ & 0 & 33,0 & $\mathrm{~d}$ & 54,97 \\
\hline RZ2A 2.2 & 100,0 & $\mathrm{a}$ & 0 & 16,7 & $\mathrm{e}$ & 78,39 \\
\hline RZ2B 2.1 & 100,0 & $\mathrm{a}$ & 0 & 50,0 & $\mathrm{c}$ & 35,31 \\
\hline RZ2E 1.1 & 100,0 & $\mathrm{a}$ & 0 & 75,0 & $\mathrm{a}$ & 2,97 \\
\hline RZ1A 2.2 & 100,0 & $\mathrm{a}$ & 0 & 50,0 & $\mathrm{c}$ & 35,31 \\
\hline RZ1A 1.2 & 100,0 & $\mathrm{a}$ & 0 & 75,0 & $\mathrm{a}$ & 2,97 \\
\hline RZ1A 1.3 & 100,0 & $\mathrm{a}$ & 0 & 75,0 & $\mathrm{a}$ & 2,97 \\
\hline RZ1B 2.1 & 100,0 & $\mathrm{a}$ & 0 & 50,0 & $\mathrm{c}$ & 35,31 \\
\hline RZ1C 2.1 & 100,0 & $\mathrm{a}$ & 0 & 50,0 & $\mathrm{c}$ & 35,31 \\
\hline RZ2E 1.3 & 40,0 & $\mathrm{~b}$ & 20,00 & 5,5 & fg & 92,88 \\
\hline RZ1C 1.1 & 40,0 & $\mathrm{~b}$ & 20,00 & 50,0 & $\mathrm{c}$ & 35,31 \\
\hline RZ2C 2.2 & 40,0 & $\mathrm{~b}$ & 20,00 & 8,3 & $\mathrm{f}$ & 89,26 \\
\hline RZ1D 1.1 & 60,0 & $\mathrm{bc}$ & 40,00 & 16,7 & $\mathrm{e}$ & 78,39 \\
\hline RZ1D 1.2 & 60,0 & $\mathrm{bc}$ & 40,00 & 16,7 & $\mathrm{e}$ & 78,39 \\
\hline RZ1E 1.1 & 60,0 & $\mathrm{bc}$ & 40,00 & 8,3 & $\mathrm{f}$ & 89,26 \\
\hline RZ2C 1.1 & 80,0 & $\mathrm{~cd}$ & 20,00 & 8,3 & $\mathrm{f}$ & 89,26 \\
\hline RZ1C 2.2 & 80,0 & $\mathrm{~cd}$ & 20,00 & 8,3 & $\mathrm{f}$ & 89,26 \\
\hline RZ1A 1.1 & 80,0 & $\mathrm{~cd}$ & 20,00 & 16,0 & $\mathrm{e}$ & 79,30 \\
\hline RZ1A 2.1 & 0 & $\mathrm{~d}$ & 100,00 & 0 & $\mathrm{~g}$ & 100,00 \\
\hline RZ1E 1.2 & 0 & $\mathrm{~d}$ & 100,00 & 0 & $\mathrm{~g}$ & 100,00 \\
\hline RZ1E 2.1 & 0 & $\mathrm{~d}$ & 100,00 & 0 & $\mathrm{~g}$ & 100,00 \\
\hline RZ2B 1.1 & 0 & $\mathrm{~d}$ & 100,00 & 0 & $\mathrm{~g}$ & 100,00 \\
\hline RZ2C 2.1 & 0 & $\mathrm{~d}$ & 100,00 & 0 & $\mathrm{~g}$ & 100,00 \\
\hline RZ2E 1.2 & 0 & $\mathrm{~d}$ & 100,00 & 0 & $\mathrm{~g}$ & 100,00 \\
\hline RZ2E 2.1 & 0 & $\mathrm{~d}$ & 100,00 & 0 & $\mathrm{~g}$ & 100,00 \\
\hline
\end{tabular}

Keterangan: Angka-angka yang diikuti oleh huruf kecil yang sama pada lajur yang sama berbeda tidak nyata menurut LSD pada taraf 5\%

Kemampuan isolat rizobakteri indigenos dalam menekan kejadian dan keparahan penyakit banding perlakuan kontrol negatif (diinokulasi $G$. boninense tanpa diintroduksi isolat RBI) dapat terlihat pada (Gambar 3). Ketujuh isolat tersebut diduga memiliki mekanisme langsung melalui aktivitas kitinase dan juga melalui mekanisme secara tidak langsung dengan menginduksi ketahanan tanaman secara sistemik atau dikenal dengan Induced Systemic Resistance (ISR). Induksi ketahanan pada tanaman oleh rizobakteri terjadi melalui beberapa mekanisme diantaranya mempengaruhi respon fisiologis, biokimia, aktifitas enzim dan kandungan senyawa penghambat patogen (Agrios, 2005). Sejalan dengan hasil penelitian Buana et al., (2014) melaporkan bahwa perlakuan Bulkholderia sp pada bibit kelapa sawit dan diinokulasi G. boninense mampu menginduksi ketahanan 
bibit kelapa sawit. Selanjutnya Bakhtiar et al., (2012) melaporkan bahwa pengintroduksian bakteri Bacillus subtilis B10 mampu meningkatkan daya adaptasi bibit kelapa sawit terhadap cekaman $G$. boninense.

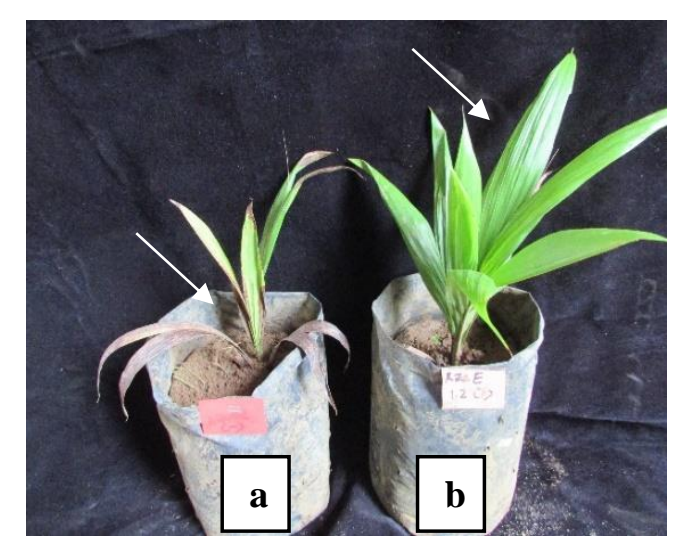

Gambar 3. Perbandingan bibit kelapa sawit yang terserang G. boninense: a. Tanaman kontrol yang terserang G. boninense dan b. Tanaman yang diintroduksi dengan isolat RZ2E 2.1 (sehat)

Hasil penelitian ini menunjukkan bahwa diperoleh dua isolat terbaik RZ2E 1.2 dan RZ2E 2.1 yang mampu meningkatkan petumbuhan tanaman dan mengendalikan perkembangan penyakit busuk pangkal batang yang disebabkan oleh G. boninense pada bibit kelapa sawit. Isolat yang diperoleh tersebut memilki peranan ganda. Penggunaan rizobakteri sebagai agen pengendalian hayati selain mempunyai potensi untuk melindungi tanaman selama siklus hidupnya, juga mampu menghasilkan hormon tumbuh sehingga memberi manfaat ganda bagi tanaman (Sutariati et al., 2014). Hasil penelitian Yanti et al., (2017) memperoleh dua strain isolat rizobakteri yang diisolasi dari rizosfer cabai (RZ.2.1.AG1 dan RZ.1.3.AP1) memiliki kemampuan paling baik dalam mengendalikan penyakit layu bakteri ( $R$. solanacearum) serta meningkatkan pertumbuhan dan hasil cabai. rizobakteri indigenos ultisol ST26c dilaporkan mampu menekan Phytophthora capsici penyebab penyakit busuk batang pada tanaman cabai dengan pesentase kejadian dan keparahan penyakit $0 \%$ tidak terjadi gejala (Khaeruni et al., 2011).

\section{KESIMPULAN DAN SARAN}

\section{Kesimpulan}

Hasil penelitian menunjukkan bahwa diperoleh dua isolat terbaik RZ2E 2.1 dan RZ2E 1.2 yang mampu meningkatkan pertumbuhan dan mampu menekan perkembangan penyakit busuk pangkal batang G. Boninense pada bibit kelapa sawit. 


\section{Saran}

Perlu dilakukannya identifikasi isolat rizobakteri indigenos yang potensial dan juga pengujian karakterisasi kemampuan PGPR dan biokontrolnya dalam mengendalikan G. boninense secara in vitro.

\section{DAFTAR PUSTAKA}

Agrios, G.N. (2005). Plant Pathology. $5^{\text {th }}$ ed. New York: Academic Press.

Bakhtiar, Y., Yahya, S., \& Sumaryono, W. (2012). Adaptation of oil palm seedlings inoculated with arbuscular mycorrhizal fungi and mycorrhizal endosymbiotic bacteria bacillus subtilis b10 towards biotic stress of pathogen Ganoderma boninense Pat. Jurnal Microbiology Indonesia, 6(4), 157-164. https://doi.org/10.5454/mi.6.4.3.

Beneduzi, A., Ambrosini, A., \& Passaglia, L. M. P. (2012). Plant growth-promoting rhizobacteria (PGPR): Their potential as antagonists and biocontrol agents. Genetics and Molecular Biology, 4, 1044-1051.

Bivi, M. R., Farhana, M. S., Khairulmazmi, A., \& Idris, A. (2010). Control of Ganoderma boninense: A causal agent of basal stem rot disease in oil palm with endophyte bacteria in vitro. International Journal of Agriculture and Biology, 12(6), 833-839.

Buana, RFN, Wahyudi AT, T.-M. N. (2014). Buana, RFN, Wahyudi AT, Toruan-Mathius N. 2014. Control activity of potential antifungal-producing Burkholderia sp. in suppressing Ganoderma growth in oil palm. Asian Journal of Agricultural Research, 8(5), 259-268.

Chong, K. P., Lum, M. S., Foong, C. P., Wong, C. M. V. L., Atong, M., \& Rossall, S. (2011). First identification of Ganoderma boninense isolated from Sabah based on PCR and sequence homology. African Journal of Biotechnology, 10(66), 14718-14723. https://doi.org/10.5897/AJB11.1096.

Fernando, W. G. D., Nakkeeran, S., \& Zhang, Y. (2005). Biosynthesis of Antibiotics by PGPR and its Relation in Biocontrol of Plant Diseases. Dordrecht, The Netherlands: Springer.

Figueiredo, M.V.B, Seldin, L, Araujo, F.F, Mariano, R. L. (2010). Plant Growth Promoting Rhizobacteria: Fundamentals and Applications. In Microbiology Monographs 18. Springer, Berlin (pp. 21-43). https://doi.org/10.1007/978-3-642-13612-2.

Halfeld-vieira, B. D. A., Roberto, J., Júnior, V., \& Romeiro, S. (2006). Induction of systemic resistance in tomato by the autochthonous phylloplane resident Bacillus cereus. Pesquisa Agropecuaria Brasileira, (1), 1247-1252.

Husen. (2003). Screening of soil bacteria for plant growth promotion activities in vitro. Indonesian Journal of Agricultural Science, 4(1), 27-31. https://doi.org/10.23919/ACC.2018.8431569.

Khaeruni, A, Sutariati, G.A.K., Rahman, A. (2011). Potensi Rizobakteri indigenous Ultisol untuk mengendalikan penyakit busuk batang Phytophthora (Phytophthora capsici) pada tanaman cabai. Jurnal Agroteknos, 1(1), 8-13.

Puspita, F, Zul D, K. A. (2013). Potential of Bacillus sp. the origin of Giam Siak Kecil Bukit Batu as Rhizobacteria as a growth and antifungal promoter in oil palm nursery. National Seminar on "The Role of Agricultural Technology and Institutions in Achieving Resilient and Sustainable 
Agricultural Development, 2009 (November), 7-15.

Rees, R. W., Flood, J., Hasan, Y., Wills, M. A., \& Cooper, R. M. (2012). Ganoderma boninense basidiospores in oil palm plantations: Evaluation of their possible role in stem rots of Elaeis guineensis. Plant Pathology, 61(3), 567-578. https://doi.org/10.1111/j.13653059.2011.02533.x.

Suryanto, D, Wibowo, R. H., Siregar EBM, M. E. (2012). A possibility of chitinolytic bacteria utilization to control basal stems disease caused by Ganoderma boninense in oil palm seedling. African Journal of Microbiology Research, 6(9), 2053-2059. https://doi.org/10.5897/ajmr11.1343.

Susanto, A., Prasetyo, A. E., Priwiratama, H., \& Wening, S. (2013). Ganoderma boninense as causal agent of upper stem rot disease of oil palm. 9(51), 123-126. https://doi.org/10.14692/jfi.9.4.123.

Susanto, A., Prasetyo, A., \& Wening, S. (2014). Laju infeksi Ganoderma pada empat kelas tekstur tanah. Jurnal Fitopatologi Indonesia, 9(2), 39-46. https://doi.org/10.14692/jfi.9.2.39.

Susanto, A., Sudharto, P. S., \& Purba, R. Y. (2005). Enhancing biological control of basal stem rot disease (Ganoderma boninense) in oil palm plantations. Journal Mycopathologia, 153-154.

Sutariati, G. A. K., Rakian, T. C., Sopacua, N., \& Mudi, L., \& Haq, M. (2014). Kajian potensi rizobakteri pemacu pertumbuhan tanaman yang diisolasi dari rizosfer padi sehat. Jurnal Agroteknos, 4(2), 71-77.

Yanti, Y, Astuti FF, Habazar T, N. C. R. (2017). Screening of rhizobacteria from rhizosphere of healthy chili to control bacterial wilt disease and to promote growth and yield of chili. Jurnal Biodiversitas, 18(1), 1-9. https://doi.org/10.13057/biodiv/d180101.

Yanti, Y., Habazar, T., Resti, Z., \& Suhalita, D. (2013). Screening of indigenous rhizobacteria from healthy soybean root to control bacterial pustule (Xanthomonas axonopodis pv. glycines) using in planta technique. J. HPT Tropika., 13(1), 24-34.

Zhang, J., Ella, J., Harris, C., Campos, F., Pereira, M., Wu, F., \& Blakeslee, J. J. (2016). DAO1 catalyzes temporal and tissue-specific oxidative inactivation of auxin in Arabidopsis thaliana. Proc Natl Acad Sci USA, 113(39), 1-6. https://doi.org/10.1073/pnas.1604769113. 